\title{
Identifikasi Faktor Yang Mempengaruhi Kemiskinan Di Provinsi Bengkulu
}

\author{
Mintargo $\cdot$ Barika $\cdot$ Edy Rahmanty
}

\begin{abstract}
The purpose of this research is to analyze the effect of unemployment with skill (X1), amount of population (X2), and minimum of wage region (X3) against proverty ( $\mathrm{Y}$ ) in Bengkulu Province. The method of analysis by an Ordinary Least Square (OLS). The data that used in this research is pooled data from BPS (Badan Pusat Statistik) of Bengkulu Province and Bapenas (period of data is 2009 - 2013 ). From the output of regression with Eviews (econometric views) aplication indicated that amount of population (X2) having significant effect against proverty (Y). unemployment with skill (X1) is not significant with proverty (Y), and the last minimum of wage region (X3) isnot significant too with proverty $(\mathrm{Y})$. The coefisien regression of variables are coefisien regress of X1 aqual -0.0001200 , coefisien regress of X2 equal 0.000200 , and coefisien regress of $\mathrm{X} 3$ equal $-5.18 \mathrm{E}-06$.
\end{abstract}

Keywords : Unemployment, Population, Wage, Poverty

(C)2018 Universitas Prof. Dr. Hazairin, SH.

\section{Latar Belakang}

Perkembangan jumlah penduduk miskin di Indonesia saat ini masih sangat berfluktuatif pada level yang cukup tinggi. Tahun 1996 jumlah penduduk miskin sebanyak 34 juta jiwa atau 17,47\% dari total jumlah penduduk. Angka ini melonjak tajam ketika terjadi krisis ekonomi tahun 1997-1998, dimana jumlah penduduk miskin mencapai hampir 50 juta jiwa, (24,2\%) dan sedikit menurun pada tahun 1999 menjadi 47,2 juta jiwa. Pada tahun 2000, jumlah penduduk miskin mulai menurun menjadi 38,7 juta atau $19,1 \%$ dan

\section{Mintargo.}

Fakultas Ekonomi dan Bisnis Universitas Bengkulu

\section{Barika $(\varangle)$}

Fakultas Ekonomi dan Bisnis Universitas Bengkulu

Email: barika_ramli@yahoo.co.id

\section{Edy Rahmantyo}

Fakultas Ekonomi dan Bisnis Universitas Bengkulu 
terus berlanjut hingga menjadi sebanyak 35 juta jiwa atau 15,9\% di tahun 2005 (Zulyanto, 2010: 102).

Indonesia secara bertahap mulai menurunkan angka kemiskinan. Pada tahun 2007 hingga 2013, Indonesia telah berhasil mengurangi kemiskinan dari 39,3 juta jiwa menjadi 28,55 juta jiwa ini berarti dalam kurun waktu tersebut indonesia telah mengurangi kemiskinan sebesar 10,75 juta jiwa dalam kurun waktu lima tahun (BPS Indonesia, 2015).

Secara geografis, distribusi penduduk miskin masih terfokus di pulau jawa dengan presentase sebesar $58 \%$ penduduk miskin berada di pulau jawa, diikuti dengan pulau Sumatra sebesar 20\% pada 2010 (Zulyanto, 2010: 132) . Namun pada 2012 jumlah penduduk miskin terbesar terdapat di papua dan maluku sebesar $24,14 \%$ dan terendah terdapat di kalimantan dengan presentase sebesar $6,48 \%$, sedangkan pulau sumatera berada diurutan ketiga dengan peroleh angka kemiskinan sebesar 11,72\% (Yenti, 2012:2).

Provinsi Bengkulu yang berada di urutan ke dua sepulau Sumatera ini menunjukkan bahwa masih banyaknya penduduk di provinsi Bengkulu yang hidup di bawah garis kemiskinan.

Tabel 1.1 Tingkat Kemiskinan Provinsi Bengkulu

\begin{tabular}{lcl}
\hline \multicolumn{1}{c}{ Uraian } & $\mathbf{2 0 1 2}$ & $\mathbf{2 0 1 3}$ \\
\hline Jumlah penduduk miskin (Ribu Orang) & 311,67 & 327,35 \\
Presentase penduduk miskin (persen) & 17,70 & 18,34 \\
Garis kemiskinan (Rp/Kapita/Bulan) & 263.05 & 296,17 \\
\hline
\end{tabular}

Sumber: BPS Prov. Bengkulu dalam angka 2013

Tabel 1.1 menunjukkan bahwa teradapat kenaikan jumlah penduduk miskin di provinsi Bengkulu. Dari 311,67 ribu orang pada 2012 menjadi 327,35 ribu orang pada 2013. Ukuran kasar dari kemakmuran masyarakat adalah pendapatan perkapita yang diperoleh melalui distribusi pendapatan nasional kepada penduduk. Melalui jalur ini masyarakat akan semakin makmur (Sukirno, 2010: 331). Namun tidak dapat dihindari bahwa tingginya angka kemiskinan di suatu tempat tidak hanya di karenakan rendahnya pendapatan perkapita, namun terdapat faktor lain yang meliputi kemiskinan.

Masalah kemiskinan selalu berkaitan dengan masalah lainya yang saling mempengaruhi seperti pertumbuhan penduduk, pengangguran, dan pendapatan. laju pertumbuhan penduduk yang terlalu cepat dianggap sebagai suatu permasalahan serius, karena dapat memicu masalah ekonomi dan sosial seperti kemiskinan absolut, ketimpangan pendapatan dan pengangguran yang tinggi (Todaro, 2000:288) pengangguran mengakibatkan tingkat distribusi pendpatan antara masyarakat menengah kebawah dan masyarakat menengah ke atas menjadi jauh. Keterkaitan antara kenaikan jumlah penduduk miskin dan jumlah penduduk tentu disebabkan banyak faktor. Salah satunya kurangnya lapangan kerja sedangkan pertumbuhan penduduk terus terjadi. Hal ini tentu memicu pengangguran terbuka.

Terjadinya kenaikan tingkat pengangguran terbuka di provinsi Bengkulu. Pada tahun 2011 total jumlah pengangguran di provinsi Bengkulu mencapai 21.215 jiwa dengan jumlah pengangguran tamatan SMA, Diploma dan Sarjana mendominasi mencapai 12.780 jauh lebih tinggi dibanding dengan tingkat pengangguran lulusan SLTP, SD dan yang tidak sekolah yang hanya 8.435 jiwa. Pada tahun 2012 terjadi 
kenaikan tingkat penganguran menjadi 31.128, 19.835 jiwa diantaranya adalah penganguran yang mengenyam pendidikan SMA, Diploma, dan Sarjana. Sedangkan sisanya yaitu sebesar 11.275 jiwa adalh pengangguran yang hanya mengenyam pendidikan SLTP, SD dan tidak bersekolah. Di tahun 2013 kembali terjadi kenaikan tingkat pengangguran di Provinsi Bengkulu. Pengangguran naik 8.767 jiwa, sehingga pada tahun 2013 jumlah penduduk yang menganggura adalah 39.895 jiwa. Sebanyak 24.402 jiwa diantaranya adalah penganguran terdidik dan sisanya 15.439 jiwa adalah mereka yang hanya lulusan SLTP, SD, dan yang tidak sekolah.

Berdasarkan data di atas dapat dilihat bahwa ada keterkaitan antara pengangguran terdidik dan jumlah total pengangguran, karena berdasarkan data di atas pengangguran terdidik memiliki jumlah lebih banyak daripada pengagguran tidak terdidik. Semua ahli ekonomi menduga bahwa pengangguran banyak dipengaruhi oleh variabel - variabel ekonomi, antara lain pertumbuhan ekonomi bersangkutan, inflasi, serta besaran upah yang berlaku. Jika upah naik akan mengurangi jumlah penggangguran( Sukirno, 2008 dalam Alghafari, 2010 ;22) hal ini akan menurunkan kemiskinan. Tingkat upah minimum provinsi Bengkulu dari tahun ke tahun cenderung mengalami kenaikan. Kenaikan tersebut dilakukan sesuai dengan kenaikan tingkat kebutuhan hidup masyarakat di Bengkulu. Adapun rumusan masalah dalam penelitian ini adalah identifikasi faktor yang mempengaruhi kemiskinan di Provinsi Bengkulu.

\section{Landasan Teori}

\subsection{Kemiskinan}

Kemiskinan adalah kondisi dimana seseorang atau suatu kelompok hidup dibawah garis kemiskinan dengan standar hidup yang rendah. Sebagai akibat dari standar hidup yang relatif rendah karna tingkat pendaptan yang rendah, ketimpangan pendapatan yang parah, dll. Sebutan standar hidup adalah manifestasi perbandingan jumlah pendapatan, perumahan, pendidikan, kesehatan, angka kematian, serta peluang mendapat pekerjaan (Todaro,2000:52)

Badan Pusat Statistik (BPS, 2015) menggunakan batas kemiskinan dari besarnya Rupiah yang dibelanjakan perkapita sebulan untuk memenuhi kebutuhan minimum makanan dan bukan makanan. Untuk kebutuhan minimum makanan digunakan patokan 2100 kalori perhari. Sedangkan pengeluaran harian minimum bukan makananan meliputi pengeluaran perumahan, sandang, serta aneka barang dan jasa. Sedangkan Bank Dunia menggunakan pendapatan perkapita sebagai batas kemiskinan, Bank dunia mengukur kemiskinan absolut dengan tidak tercapainya penghasilan sebesar US \$1.25 per hari di tahun 2010. Pendapatan bagi Kemiskinana relatif berkisar antara US \$ $1.25-$ $\$ 2.00$ per hari di tahun 2010 .

Mengidentifikasi mengenai penyebab kemiskinan, terdapat banyak versi. Menurut Kuncoro (2000:107) dipandang dari sisi ekonomi penyebab kemiskinan antara lain, Pertama, secara mikro kemiskinana timbul akibat ketidaksamaan pola pemikiran sumber daya yang menimbulkan distribusi pendapatan yang timpang. Kedua, kemiskinan timbul akibat ketidaksamaan dalam kualitas sumber daya manusia. Ketiga, kemiskinan muncul akibat perbedan akses modal. Namun, Kartasasmita dalam Endayani (2010:18) Terdapat empat faktor yang menjadi penyebab terjadinya fenomena kemiskinan, yaitu :

1. Rendahnya tingkat pendidikan

2. Redahnya derajat kesehatan

3. Terbatasanya lapangan kerja

4. Kondisi keterisolasian 


\subsection{Pengangguran}

Penganggur adalah suatu keadaan di mana seseorang tergolong dalam angkatan kerja yang ingin mendapat pekerjaan tetapi belum dapat memperoleh pekerjaan tersebut (Sukirno, 2010: 472). Sedangkan pada Sumarsono (2009: 259) pengangguran adalah seseorang atau lebih yang berada dalam kategori angkatan kerja yang tidak memiliki pekerjaan atau secara aktif sedang dalam pencarian pekerjaan.

Ketidak seimbangan permintaan dan penawaran tenaga kerja berdampak pada perekonomian suatu negara, Todaro (2000:320), sebagian besar pengangguran adalah merupakan kelompok masyarakat paling miskin, yang tidak memiliki pekerjaan teratur atau yang bekerja secara musiman. Namun tidak setiap orang yang tidak bekerja pasti miskin, selalu saja ditemukan pengangguran sukarela di negara berkembang, yaitu yang dengan mudah dapat memperoleh pekerjaan yang baik, tapi memilih menganggur karna jenis pekerjaan tidak sesuai dengan pendidikan, kualifikasi kecakapan, aspirasi pribadi, target finansial maupun standar gengsi.

\subsection{Teori Pertumbuhan Penduduk}

Pertumbuhan penduduk adalah pertambahan jumlah populasi penduduk suatu negara. Pertumbuhan penduduk yang cepat akan mendorong timbulnya masalah keterbelakangan yang membuat prospek pembangunan menjadi semakin jauh. Di negara berkembang laju pertumbuhan penduduk yang terlalu cepat dianggap sebagai suatu permasalahan serius, karena dapat memicu masalah ekonomi dan sosial seperti kemiskinan absolut, ketimpangan pendapatan dan pengangguran yang tinggi (Todaro, 2000:288)

Terjadinya peningkatan jumlah penduduk yang cukup tajam menandai masuknya era modern dari sejarah demografi yang dinyatakan sebagai transisi demografi tahap kedua. Transisi demografi ini terjadi bersamaan dengan perubahan pembangunan dan prtumbuhan ekonomi modern. Perubahan prilaku masyarakat agraris ke masyarakat modern bersamaan dengan terjadinya indutrialisasi dan urbanisasi yang dianggap memiliki dampak pada perubahan demografi dan ekonomi (Yasin dan Adioetomo, 2010: 13).

Menurut Yasin dan Adioetomo (2010: 6), pertumbuhan penduduk diakibatkan oleh tiga komponen demografi, yaitu:
a. fertilitas
b. mortalitas
c. migrasi

Menurut karakteristik ekonomi, penduduk dapat dikelompokkan berdasarkan lapangan usaha, jenis pekerjaan dan status pekerjaan yang secara ekonomi mpengaruhi tingkat kesejahteraan rumah tangga (Nurdin dan Adioetomo, 2010: 27).

\subsection{Upah Minimum Regional}

Upah adalah suatu penerimaan sebagai imbalan dari pengusaha kepada karyawan untuk suatu pekerjaan atau jasa yang telah dilakaukan dan dinyatakan atau diniai dalam bentuk uang yang ditetapkan atas dasar suatu persetujuaan atau peraturan perundang undangan serta dibayarkan atas dasar suatu perjanjian kerja antara pengusaha dan karyawan termasuk tunjangan, baik untuk karyawan itu sendiri maupun keluarganya. Upah minimun adalah upah yang ditetapkan secara minimum regional, sektor regional maupun sektor subsektoral yang berupa upah pokok dan tunjangan (Sumarsono, 2009 :151). Jumlah upah minimum haruslah dapat memenuhi kebutuhan hidup pekerja secara 
minimal yaitu, memenuhi kebutuhan untuk sandang pangan keperluan rumah tangga dan kebutuhan dasar lainnya, apabila kenaikan jumlah kebutuhan tidak diikuti kenaikan upah minimun akan memicu kenaikan angka kemiskinan (Sumarsono, 2009 : 151).

\section{Data dan Metode Analisis}

Studi menggunakan data panel 10 Kabupaten/Kota di Provinsi Bengkulu selama tahun 2009 - 2013. Metode analisa yang digunakan adalah metode analisis deskriptif kuantitatif, yaitu membahas hasil hasil penelitian berdasarkan perhitungan angka angka sesuai dengan permasalahan yang diangkat dalam penelitian ini. Untuk menganalisis tentang analisis tingkat pengangguran terdidik, jumlah penduduk, dan UMR terhadap kemiskinan di Provinsi Bengkulu, maka metode yang digunakan adalah metode regresi linier berganda, yaitu sebagai berikut:

$$
\mathbf{Y}=\mathbf{a}+\mathbf{b} 2 \mathbf{X} 1+\mathbf{b} 2 \mathbf{X} 2+\mathbf{b} 3 \mathbf{X} 3+\mathbf{e}
$$

\begin{tabular}{|c|c|}
\hline \multicolumn{2}{|c|}{ Keterangan } \\
\hline Y & : tingkat kemiskinan \\
\hline $\mathrm{a}$ & Konstanta \\
\hline $\mathrm{X} 1$ & : $\quad$ tingkat pengangguran terdidik \\
\hline $\mathrm{X} 2$ & jumlah penduduk \\
\hline $\mathrm{X} 3$ & Upah minimum Regional \\
\hline
\end{tabular}

Adapun operasionalisasi variabel adalah sebagai berikut;

1. Kemiskinan adalah jumlah penduduk miskin Provinsi Bengkulu 2009 sampai 2013 dalam jumlah orang per kabupaten di Provinsi Bengkulu.

2. Pengangguran terdidik adalah jumlah pengangguran lulusan SMA, Diploma, dan Sarjana di Provinsi Bengkulu tahun 2009 sampai 2013 dalam jumlah orang per kabupaten di Provinsi Bengkulu

3. jumlah penduduk adalah jumlah pertumbuhan penduduk Provinsi Bengkulu 2009 sampai 2013 dalam jumlah orang per kabupaten di Provinsi Bengkulu

4. Upah minimun Regional adalah upah minimum Provinsi Bengkulu 2009 sampai 2013 dalam rupiah per kabupaten di Provinsi Bengkulu

\section{4.. Hasil Penelitian}

\subsection{Hasil penelitian dan Interpretasi Data}

a. Perkembangan Tingkat Pengangguran Terdidik Provinsi Bengkulu

Pengangguran terdidik adalah jumlah angkatan kerja yang menganggur dengan memiliki Ijazah SMA / SMK, Diploma, dan Sarjana. Di Provinsi Bengkulu sendiri angka pengangguran terdidik bergerak fluktuatif setiap tahunnya. Terjadi peningkatan dan penurunan, meskipun dalam angka yang sedikit. 
Tabel 4.1 Data penduduk Provinsi Bengkulu yang termasuk pengangguran terdidik

\begin{tabular}{llrrrrr}
\hline \multirow{2}{*}{ NO } & NAMA & \multicolumn{5}{c}{ JUMLAH PENGANGGURAN TERDIDIK } \\
\cline { 3 - 7 } & KABUPATEN & $\mathbf{2 0 0 9}$ & $\mathbf{2 0 1 0}$ & $\mathbf{2 0 1 1}$ & $\mathbf{2 0 1 2}$ & $\mathbf{2 0 1 3}$ \\
\hline \hline 1 & Bengkulu Selatan & 2,886 & 1,930 & 510 & 1,374 & 1,783 \\
2 & Rejang Lebong & 3,440 & 2,616 & 1,553 & 1,457 & 3,466 \\
3 & Bengkulu Utara & 3,441 & 1,684 & 1,498 & 1,960 & 1,876 \\
4 & Kaur & 1,664 & 787 & 865 & 1,335 & 2,096 \\
5 & Seluma & 1,650 & 1,676 & 1,113 & 788 & 1,413 \\
6 & Muko Muko & 1,150 & 1,353 & 593 & 819 & 739 \\
7 & Lebong & 1,233 & 1,028 & 1,047 & 933 & 1,365 \\
8 & Kepahiang & 1,314 & 1,813 & 1,393 & 1,203 & 1,649 \\
9 & Bengkulu Tengah & 0 & 934 & 973 & 1,115 & 2,356 \\
10 & Kota Bengkulu & 12,250 & 11,437 & 3,235 & 8,869 & 7,659 \\
& JUMLAH & $\mathbf{2 9 , 0 2 8}$ & $\mathbf{2 5 , 2 5 8}$ & $\mathbf{1 2 , 7 8 0}$ & $\mathbf{1 9 , 8 5 3}$ & $\mathbf{2 4 , 4 0 2}$ \\
\hline \hline
\end{tabular}

Sumber: Bengkulu Dalam Angka dalam berbagai tahun

Jika di amati perkabupaten / kota di Provinsi Bengkulu, tingkat penggangguran terdidik paling tinggi hingga 2013 ditempati oleh kota bengkulu dengan perolehan mencapai 7,659 jiwa. Kemudian disusul oleh kabupaten Rejang Lebong dengan tingkat penggangguran terdidik mencapai 3,466 jiwa di 2013, sangat jauh jika dibandingkan dengan tingkat penggguran terididik yang ada di kota Bengkulu yang mencapai 7,659 jiwa di 2013. Urutan ketiga ditempati oleh kabupaten Bengkulu Tengah dengan tingkat pengangguran teridik sejumlah 2,356 jiwa di 2013, disusul oleh kabupaten Kaur dengan jumlah pengangguran terdidik mencapai 2,096 jiwa juga pada tahun yang sama. Kemudian diikuti oleh kabupaten lainnya berdasarkan urutan paling tinggi kepada urutan terrendah seprovinsi Bengkulu, yaitu Kabupaten Bengkulu Utara dengan jumlah pengangguran terdidik mencapai 1,876 jiwa di tahun 2013, Kabupaten Bengkulu Selatan adalah 1,783 jiwa ditahun 2013, kabupaten Kepahiang 1,649 jiwa yang menjadi pengangguran terdidik, angka ini disusul oleh kabupaten lain seperti Seluma, Lebong dan Muko Muko yang adalah kabupaten dengan jumlah pengangguran terdidik paling rendah di Provinsi Bengkulu.

\section{b. Pertumbuhan Penduduk Provinsi Bengkulu}

Pertumbuhan jumlah penduduk merupakan salah satu indikator ekonomi yang penting untuk melihat sisi ekonomi lian yang ada di Provinsi Bengkulu. Provinsi Bengkulu dengan 9 Kabupaten dan 1 kota tentu memiliki jumlah penduduk yang cukup banyak, meskipun bukan menjadi Provinsi terpadat penduduk di Indonesia. Jika kita melihat perkabupaten dan kota yang ada di Provinsi Bengkulu terlihat bahwa hampir setiap kabupaten mengalami kenaikan jumlah penduduk yang signifikan, meskipun adapula suatu kabupaten mengalami penurunan jumlah penduduk seperti yang terlihat di tabel Tabel 4.3, Kabupaten Rejang Lebong pada 2010 dengan jumlah penduduk 257,675 jiwa mengalami penurunan dengan tahun sebelumnnya di tahun 2009 jumlah penduduk di Kabupaten Rejang Lebong 257,563 jiwa. Namun angka tersebut tidak lebih tinggi dari angka di tahun setelahnya. 
Tabel 4.2 jumlah penduduk menurut kabupaten / kota Di Provinsi Bengkulu

\begin{tabular}{clrrrrr}
\hline \hline & NAMA & \multicolumn{7}{c}{ JUMLAH PENDUDUK } & \multicolumn{1}{c}{ (013 } \\
\cline { 3 - 7 } NO & KABUPATEN & \multicolumn{1}{c}{$\mathbf{2 0 0 9}$} & $\mathbf{2 0 1 0}$ & $\mathbf{2 0 1 1}$ & $\mathbf{2 0 1 2}$ & $\mathbf{2 0 1 3}$ \\
\hline \hline 1 & Bengkulu Selatan & 142,964 & 142,940 & 145,153 & 146,891 & 148,854 \\
2 & Rejang Lebong & 257,563 & 246,787 & 250,608 & 250,986 & 253,020 \\
3 & Bengkulu Utara & 253,052 & 257,675 & 261,665 & 268,921 & 275,858 \\
4 & Kaur & 117,821 & 107,899 & 109,569 & 110,921 & 112,894 \\
5 & Seluma & 165,564 & 173,507 & 176,193 & 178,689 & 181,242 \\
6 & Muko Muko & 145,530 & 155,753 & 158,164 & 161,087 & 168,654 \\
7 & Lebong & 92,579 & 99,215 & 100,751 & 102,126 & 105,421 \\
8 & Kepahiang & 118,910 & 124,865 & 126,798 & 127,047 & 129,706 \\
9 & Bengkulu Tengah & 94,106 & 98,333 & 99,855 & 101,028 & 104,179 \\
10 & Kota Bengkulu & 278,831 & 308,544 & 313,324 & 319,098 & 334,529 \\
& Jumlah & $\mathbf{1 , 6 6 6 , 9 2 0}$ & $\mathbf{1 , 7 1 5 , 5 1 8}$ & $\mathbf{1 , 7 4 2 , 0 8 0}$ & $\mathbf{1 , 7 6 6 , 7 9 4}$ & $\mathbf{1 , 8 1 4 , 3 5 7}$ \\
& & & & & &
\end{tabular}

Sumber :Hasil Survei Sosial Ekonomi Nasional (susenas) 2012 dan Bengkulu Dalam Angka Berbagai tahun

c. Tingkat Upah Minimum Regional / Provinsi Bengkulu

Tingkat upah minimum merupakan standar minimum untuk pembayaran upah pekerja atau buruh. Upah minimun regional ditentukan berdasarkan pertimbangan kebutuhan hidup minimum, indeks harga konsumen, upah minimun yang berlaku secara regional kemampuan dan tingkat perkembangan perusahaan. Perkembangan tingkat upah minimum regional dapat dilihat pada table 4.3.

Tabel 4.3 Upah Minimum Regional / Upah Minimum Provinsi Bengkulu

\begin{tabular}{cll}
\hline \hline & \multicolumn{2}{c}{ Upah Minimum Regional (Rupiah) } \\
\cline { 2 - 3 } Tahun & UMR perhari & UMR perbulan \\
\hline 2009 & 29,400 & 735,000 \\
2010 & 31,200 & 780,000 \\
2011 & 32,600 & 815,000 \\
2012 & 37,200 & 930,000 \\
2013 & 48,000 & $1,200,000$ \\
\hline \hline Sumber: Dinas & Tenaga Kerja dan & Transmigrasi Provinsi Bengkulu \\
Dalam Bengkulu Dalam Angka 2015 &
\end{tabular}

d. Perkembangan Tingkat Kemiskinan Provinsi Bengkulu

secara keseluruhan jumlah penduduk yang termasuk dalam kategori miskin menurut Bengkulu Dalam Angka berbagai tahun di provinsi Bengkulu fluktuatif. Kenaikan dan penurunan jumlah penduduk miskin di provinsi Bengkulu adalah merupakan akibat keberhasilan atau kurang berhasilnya peran pemerintah dalam menanggulangi kemiskinan. Table 4.4. menguraikan jumlah penduduk miskin di Provinsi Bengkulu. 
Tabel 4.4 Jumlah Penduduk Miskin Di Provinsi Bengkulu

\begin{tabular}{llccccc}
\hline & NAMA & \multicolumn{5}{c}{ JUMLAH PENDUDUK MISKIN (000) } \\
\cline { 3 - 7 } NO & KABUPATEN & $\mathbf{2 0 0 9}$ & $\mathbf{2 0 1 0}$ & $\mathbf{2 0 1 1}$ & $\mathbf{2 0 1 2}$ & $\mathbf{2 0 1 3}$ \\
\hline \hline 1 & Bengkulu Selatan & 37.7 & 32.4 & 32.8 & 33.6 & 33.7 \\
2 & Rejang Lebong & 42.8 & 37.3 & 42.2 & 43.1 & 46.8 \\
3 & Bengkulu Utara & 58.7 & 38.3 & 37.8 & 37.7 & 40.2 \\
4 & Kaur & 29.1 & 37.0 & 24.4 & 25.1 & 26.3 \\
5 & Seluma & 40.1 & 44.0 & 36.9 & 37.8 & 39.7 \\
6 & Muko Muko & 23.6 & 26.0 & 21.1 & 21.6 & 22.0 \\
7 & Lebong & 20.7 & 23.0 & 12.6 & 19.5 & 21.0 \\
8 & Kepahiang & 13.6 & 25.0 & 19.1 & 12.9 & 13.7 \\
9 & Bengkulu Tengah & & 7.0 & 6.5 & 6.7 & 7.6 \\
10 & Kota Bengkulu & 51.5 & 54.8 & 69.9 & 71.5 & 72.4 \\
& Jumlah & $\mathbf{3 1 7 . 8}$ & $\mathbf{3 2 4 . 9}$ & $\mathbf{3 0 3 . 3}$ & $\mathbf{3 0 9 . 5}$ & $\mathbf{3 2 3 . 4}$ \\
\hline \hline
\end{tabular}

Sumber : Provinsi Bengkulu Dalam Angka Berbagai Tahun

\subsection{Hasil Penelitian}

Berdasarkan output regresi linier menggunakan Eviews, model regresi linier berganda yang digunakan dalam penelitian ini dapat dirumuskan sebagai berikut :

\section{Kemiskinan $=1.816049-0.000148$ Pengangguran Terdidik +0.000200 Jumlah Penduduk - 5.18E-06 UMR}

Pengujian F-Statistik digunakan untuk menguji signifikasi dari semua variabel bebas sebagai suatu kesatuan atau mengukur pengaruh variabel bebas secara bersama sama. Pengujian dilakukan menggunakan distribusi F dengan cara membandingkan nilai F- hitung yang diperoleh dari hasil regresi dengan F-tabelnya .

Dari hasil analisis regresi menunjukkan F-hitung (F-Statistik) sebesar 16.38688 dan F-tabel (3.415389) dengan $\mathrm{N}_{1}=3 \mathrm{~N}_{2}=50$ pada level 0.05 adalah dengan demikian Fhitung (16.38688) > F-tabel (3.415389), artinya variabel independen berpengaruh signifikan terhadap variabel dependen. Atau secara bersama - sama variabel independen mempengaruhi tingkat kemiskinan secara signifikan pada tingkat kepercayaan $95 \%$.

Tabel 4.5. Hasil Estimasi

\begin{tabular}{lllll}
\hline \hline Variable & Coefficient & Std. Error & t-Statistic & Prob. \\
\hline \hline C & 1.816049 & 6.105316 & 0.297454 & 0.7675 \\
PENGANGGURAN? & -0.000148 & 0.000567 & -0.260411 & 0.7957 \\
PENDUDUK? & 0.000200 & $2.90 \mathrm{E}-05$ & 6.909200 & 0.0000 \\
UMR? & $-5.18 \mathrm{E}-06$ & $4.57 \mathrm{E}-06$ & -1.132683 & 0.2633 \\
\hline \hline
\end{tabular}




\subsection{Pembahasan}

Berdasarkan hasil perhitungan secara parsial (uji-t) menyatakan bahwa pengangguran terdidik tidak memiliki pengaruh yang signifikan terhadap tingkat kemiskinan di Provinsi Bengkulu, meskipun jika dilihat pada data jumlah pengangguran terdidik di Provinsi Bengkulu peningkatannya diiringi pula oleh kenaikan jumlah penduduk miskin.

Dari hasil perhitungan regresi diketahui bahwa nilai koefisien regresi variabel tingkat pengangguran terdidik adalah -0.000148 dan t- hitung adalah -0.260411. dimana t- hitung lebih kecil dari t- tabel (-2.01289), sehingga tingkat pengangguran terdidik tidak memiliki pengaruh terhadap tingkat kemiskinan. Penelitian ini sesuai dengan hasil penelitian sebelumnya yang dilakukan oelh Ari Juanda (2010) yang berjudul Analisis Kausalitas PDRB, Pendidikan dan pengangguran terhadap kemiskinan Provinsi Bengkulu, yang menunjukkan bahwa antara pertumbuhan ekonomi, Pendidikan, pengangguran dengan kemiskinan tidak memiliki hubungan kausalitas.

Selanjutnya dari jumlah perhitungan regresi yang dilakukan dengan menggunakan Eviews diketahui bahwa koefisien regresi pada variabel jumlah penduduk adalah 0.000200 dan diketahui $t$ hitung adalah 6.909200. $t$ hitung lebih besar dari t tabel (2.01289), maka jumlah penduduk memiliki pengaruh signifikan tehadap kemiskinan di Provinsi Bengkulu. Pada penelitian yang dilakukan untuk variabel UMR provinsi Bengkulu., didapat hasil estimasi menggunakan eviews koefiesien UMR adalah -5.18E06, sedangkan $t$ statiskik atau t hitungnya adalah -1.132683 lebih kecil dari t tabel (2.01289), ini berarti bahwa UMR tidak memiliki pengaruh terhadap tingkat kemiskinan di Provinsi Bengkulu.

\subsection{Implikasi Hasil Penelitian}

Berdasarkan hasil penelitian dapat dinyatakan bahwa tingkat kemiskinan di provinsi Bengkulu dipengaruhi oleh salah satu dari tiga variabel yang diduga memiliki pengaruh, yaitu jumlah penduduk. Hal tersebut terbukti dengan hasil perhitungan estimate menggunakan eviews. Dapat disimpulkan bahwa jumlah penduduk mempengaruhi tingkat kemiskinan di provinsi Bengkulu secara signifikan. Sedangkan untuk tingkat pengangguran terdidik dan UMR, tidak berpengaruh secara signifikan terhadap tingkat kemiskinan di Provinsi Bengkulu.

Tentunya, ada beberapa hal yang perlu dicermati melalui penelitian ini, antara lain :

a. Hal yang perlu diperhatikan masyarakat untuk mengurangi tingkat kemiskinan adalah dengan membatasi angka kelahiran, dengan menggalakan kembali program pembatasan kelahiran seperti KB. Karna seperti dapat disimak di dalam penelitian ini, jumlah penduduk mempengaruhi tingkat kemiskinan. Hingga semakin cepat pertambahan jumlah penduduk akan meningkatkan angka kemiskinan juga.

b. Bagi Instansi terkait tentunya harus lebih peka terhadap penyebab kemiskinan di Provinsi Bengkulu dan secara sigap menggatasinya. Dapat berupa mengadakan sosialisi mengenai pola dan pemberantasan kemiskinan, dikalangan terpelajar maupun memberikan bantuan yang tepat sasaran, guna meningkatkan taraf hidup masyarakat miskin.

c. Bagi peneliti selanjutnya, hasil penelitian ini dapat menjadi bahan referensi dan sebagai gambaran mengenai pengaruh pengangguran terdidik, jumlah penduduk dan UMR, terhadap kemiskinan di Provinsi Bengkulu. Namun, diharapkan untuk menambah variabelnya, demi kesempurnaan hasil penelitian selanjutny.

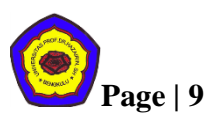




\section{Penutup}

\subsection{Kesimpulan}

Berdasarkan hasil penelitian dan pembahsan tentang pengaruh tingkat pengangguran terdidik, pertumbuhan penduduk, dan UMR terhadap kemiskinan di Provinsi Bengkulu, dapat diambil kesimpulan sebagai berikut :

1. Berdasarkan uji hipotesa serentak atau secara bersama - sama variabel independen mempengaruhi tingkat kemiskinan secara signifikan.

2. Hasil uji-t membuktikan bahwa pengangguran terdidik dan UMR tidak berpengaruh terhadap tingkat kemiskinan, sedangkan jumlah penduduk dan berpengaruh terhadap tingkat kemiskinan.

\subsection{Saran}

1. Bagi masyarakat, salah satu cara pengentasan kemiskinan yang baik adalah dengan terus bekerja keras dan meningkatkan kualitas diri, melalui bidang pendidikan, pelatihan serta penanggulangan angka kelahiran dengan mengikuti program keluarga berencana.

2. Bagi Dinas terkait agar lebih dpat memperhatikan dan merealisasikan program pegentasan kemiskinan sesuai dengan yang dibutuhkan dan tepat sasaran.

3. Bagi peneliti lain tentunya diharapkan untuk menambah atau mengganti variabel bebas yang lain sehingga dapat diketahui secara terperinci variabel apakah yang sangat mempengaruhi tingkat kemiskinan di provinsi Bengkulu.

\section{Daftar Pustaka}

BPS Indonesia. 2014. Pengangguran Terbuka Menurut Pendidikan Tertinggi yang Ditamatkan 2004 - 2014*). http://bengkulu.bps.go.id/ ( Diakses 09 Februari 2015)

Badan Pusat Statistik. 2015. Bengkulu Dalam Angka (2011 - 2013). BPS Provinsi Bengkulu

Bungin, Burhan.2005.metodelogi penelitian kuantitatif (komunikasi,ekonomi, dan ilmu - ilmu sosial lainnya). Jakarta. Prenada Media

Endayani, Tuti. 2010. Analisi Faktor - faktor yang mempengaruhi pendapatan masyarakat miskin di kecamatan bang haji kabupaten bengkulu tengah provinsi bengkulu. Arga makmur: Skripsi Fakultas Ekonomi Universitas Ratu Samban

Kuncoro.Mudrajat.,2000, Ekonomi Pembangunan: Teori, Masalah dan Kebijakan,UPP AMP YKPN, Yogyakarta

Nurdin, Harto dan Adioetomo, Moertiningsih . 2010. Komposisi Dn Distribusi Penduduk. Jakarta : Salemba Empat

Sukirno, Sadono. 2010. Teori Pengantar Makro Ekonomi Edisi Ketiga . Jakarta : PT Raja Grafindo Persada

Sumarsono, Sonny. 2009. Teori dan kebijakan publik Ekonomi Sumber Daya Manusia. Yogyakarta. Graha Ilmu

Todaro, Michael P. 2000. Pembangunan Ekonomi Dunia Ketiga Edisi Kedelapan. Jakarta : Erlangga

Yasin, Mohammad dan Adioetomo, Moertiningsih, Sri. 2010. Demografi: Arti dan Tujuan. Jakarta : Salemba Empat 
Yenti, Nasri. 2013. Pengaruh pertumbuhan Ekonomi terhadap kemiskinan di Provinsi Bengkulu. Arga makmur: Skripsi Fakultas Ekonomi Universitas Ratu Samban

Zulyanto, Aan. 2010. Peranan pertumbuhan ekonomi dalam mengurangi kemiskinan di Indonesia. Majalah Ilmiah : Universitas Ratu Samban 
PARETO : Jurnal Ekonomi dan Kebijakan Publik

Halaman sengaja dikosongkan 